\title{
PERBANDINGAN NYERI PASCA SEKSIO SESAREA PADA PENDERITA YANG DIBERIKAN KETOROLAK DAN TRAMADOL DENGAN PETIDIN
}

\author{
${ }^{1}$ Nur Fadhliyah Asimin \\ ${ }^{2}$ Lucky Kumaat \\ ${ }^{2}$ Diana Lalenoh \\ ${ }^{1}$ Kandidat Skripsi Fakultas Kedokteran Universitas Sam Ratulangi Manado \\ ${ }^{2}$ Bagian Anestesiologi dan Terapi Intensif Fakultas Kedokteran \\ Universitas Sam Ratulangi Manado \\ Email: asiminlhya@yahoo.com
}

\begin{abstract}
Anesthesia can not be separated from surgery and other medical procedures that cause pain. General anesthesia is associated with loss of consciousness (sedation), loss of perception of pain (analgesia), and suppression of motor reflexes of the body that allows the immobilization of the patient (areflexia). Pain is an unpleasant sensory and emotional experience that is associated with tissue damage that has or potentially occur, or can be explained by the damage. Postoperative pain should be adequately controlled because if the pain is not adequately relieved it can lead to discomfort and affect the pulmonary, cardiovascular, gastrointestinal, endocrine, and immunological systems. This study aimed to determine the value of post-operative pain in patients with caesarean section and to compare the value of pain after administration of ketorolac and tramadol with pethidine on $0,2,4,6$ hours. This was a prospective analytical study. There were 16 cases of cesarean section selected according to the inclusion and exclusion criteria. Patients were divided into 2 groups: the first group for the combination of ketorolac and tramadol and the second group for pethidine. The data were measured by using VAS pain scale, and were statistically analyzed by using independent $t$ test and Man Whitney $U$ test. The ketorolac and tramadol group showed an increase of VAS score averages: 0 in hour-0; 1 in hour-2; 4.5 in hour-4; and 6.5 in hour-6. The pethidine group showed the VAS score averages: 0 in hour- 0 until hour-2; 7 in hour-4; and 9.6 in hour-6. Conclusion: There were differences in the post-caesarean section pain which were significant in the hour- 4 and hour- 6 between tramadol and ketorolac group and the pethidine group. Moreover, the average value of VAS scale was lower in the ketorolac and tramadol group than of the pethidine group.
\end{abstract}

Keywords: caesarean section, VAS scale pain, ketorolac, tramadol, pethidine

\begin{abstract}
Abstrak: Anestesia tidak dapat dipisahkan dari pembedahan dan berbagai prosedur medis lain yang menimbulkan rasa sakit. Anestesi umum dihubungkan dengan hilangnya kesadaran (sedasi), hilangnya persepsi nyeri (analgesia) dan tersupresinya refleks-refleks motorik tubuh, memungkinkan imobilisasi pasien (arefleksia).Nyeri adalah suatu pengalaman sensorik dan emosional yang tidak menyenangkan yang berkaitan dengan kerusakan jaringan yang sudah atau berpotensi terjadi, atau dijelaskan berdasarkan kerusakan tersebut. Nyeri pasca operasi harus dikontrol secara adekuat sebab nyeri yang tidak diatasi secara adekuat dapat mengakibatkan ketidaknyamanan serta mempengaruhi sistem pulmonary, kardiovaskular, gastrointestinal, endokrin, dan imunologik. Penelitian ini bertujuan untuk mengetahui nilai nyeri pada pasien pasca operasi seksio sesarea dan membandingkan nilai nyeri setelah pemberian ketorolak dan tramadol dengan pemberian petidin pada jam ke 0, 2, 4, dan 6 . Penelitian ini merupakan studi analitik prospektif. Terdapat 16 kasus bedah sesar yang
\end{abstract}


memenuhi kriteria inklusi dan eksklusi. Pasien dibagi menjadi 2 kelompok, yakni kelompok I untuk kombinasi ketorolak dan tramadol; dan kelompok II untuk petidin. Data yang dikumpulkan diukur dengan skala nyeri VAS, kemudian data dianalisis dengan menggunakan uji t independent dan uji Man Whitney U. Pada skor VAS kelompok ketorolak tramadol terjadi peningkatan nilai rerata dari jam ke-0 sebesar 0; pada jam ke-2 menjadi 1; pada jam ke4 menjadi 4,5; dan pada jam ke-6 meningkat menjadi 6,5. Pada skor VAS kelompok petidin nilai rerata dari jam ke-0 sebesar 0; tetap stabil pada angka 0 pada jam ke-2; pada jam ke-4 menjadi 7; dan pada jam ke-6 menjadi 9,6. Simpulan: Terdapat perbedaan rasa nyeri yang sangat bermakna pada jam ke-4 dan jam ke-6 antara kelompok ketorolak + tramadol dan kelompok petidin. Nilai rerata VAS pada kelompok ketorolak + tramadol lebih rendah dibandingkan nilai rerata VAS pada kelompok petidin.

Kata kunci: seksio sesarea, skala nyeri, ketorolak, tramadol, petidin

Anestesia tidak dapat dipisahkan dari pembedahan dan berbagai prosedur medis lain yangmenimbulkan rasa sakit. Anestesi umum dihubungkan dengan hilangnya kesadaran (sedasi), hilangnya persepsi nyeri (analgesia) dan tersupresinya refleksrefleks motorik tubuh, memungkinkan imobilisasi pasien (arefleksia). ${ }^{1}$

Seksio sesarea merupakan suatu tindakan yang terpenting dalam bidang obstetri. Operasi ini bertujuan melahirkan janin melalui suatu insisi pada dinding rahim dengan syarat rahim dalam keadaan utuh serta berat janin di atas 500 gram. $^{2}$

Menurut The International Association for the Study of Pain nyeri adalah pengalaman sensoris dan emosional yang tidak nyaman, terkait dengan kerusakan jaringan secara aktual atau potensial. Keadaan psikis sangat memengaruhi nyeri, misalnya emosi dapat menimbulkan sakit atau memperhebatnya, tetapi dapat pula mengindarkan sensasi rangsangan nyeri. ${ }^{3}$

Nyeri pasca operasi harus dikontrol secara adekuat sebab nyeri yang tidak diatasi secara adekuat dapat mengakibatkan ketidaknyamanan serta memengaruhi sistem pernapasan, kardiovaskular, gastrointestinal, endokrin, dan imunologik. Nyeri yang tidak terkontrol dapat menyebabkan aktivitas sistem saraf simpatis, yang dapat menyebabkan berbagai tanggapan fisiologis yang berpotensi berbahaya yang dapat mempengaruhi negatif tingkat morbiditas dan mortalitas. $^{4}$

Aspek terpenting dalam prosedur anestesia ialah analgesia. Obat-obat analgesik digunakan sebagai bagian dari teknik anestesi untuk menghilangkan nyeri. ${ }^{1}$ Obat-obatan analgetika yang dipakai dalam penanganan nyeri ialah golongan Analgetik Opioid dan NSAID.

Nonsteroidal anti-inflammatory drugs (NSAID), yang meliputi aspirin dan acetaminophen, terdiri dari berbagai kelompok senyawa analgesik dengan sifat farmakokinetik yang berbeda. NSAID dibagi menjadi beberapa golongan, antara lain golongan profen/asam 2-arilpropionat (diantarana ibuprofen alminoprofen, fenbufen, imdoprofen, naproxen, dan ketorolak). ${ }^{5}$

Ketorolak merupakan satu dari sedikit AINS yang tersedia untuk pemberian parenteral. Absorpsi oral dan intramuskular berlangsung cepat mencapai puncak dalam 30-50 menit. Bioavailabilitas oral 80\% dan hampir seluruhnya terikat protein plasma. Ketorolak IM sebagai analgetik pasca bedah memperlihatkan efektivitas sebanding morfin/meperidin, masa kerjanya lebih panjang dan efek sampingnya lebih ringan. ${ }^{6}$

Ketorolak merupakan satu dari sedikit AINS yang tersedia untuk pemberian parenteral. Absorpsi oral dan intramuskular berlangsung cepat mencapai puncak dalam 30-50 menit. Bioavailabilitas oral $80 \%$ dan hampir seluruhnya terikat protein plasma. Ketorolak IM sebagai analgetik pasca bedah memperlihatkan efektivitas sebanding morfin/meperidin, masa kerjanya lebih panjang dan efek sampingnya lebih ringan. ${ }^{6}$ Tramadol adalah analog kodein sintetik yang yang merupakan reseptor $\mu(\mathrm{mu})$ yang lemah. 
Sebagian dari efek analgetiknya ditimbulkan oleh inhibisi ambilan norepinefrin dan serotonin. Bioavailabilitas tramadol setelah dosis tunggal secara oral $68 \%$ dan $100 \%$ bila digunakan secara intramuscular (IM). Analgesi timbul dalam 1 jam setelah penggunaan secara oral, dan mencapai puncakdalam 2-3 jam. Lama analgesia sekitar 6 jam. $^{6}$

Petidin ialah zat sintetik yang formulanya sangat berbeda dengan morfin, tetapi mempunyai efek klinik dan efek samping yang mendekati sama. Petidin lebih larut dalam lemak dibandingkan dengan morfin yang lebih larut dalam air. Petidin termasuk golongan opoid yang digunakan untuk menghilang-kan nyeri. Petidin yang juga dikenal sebagai meperidin. Efek analgetik petidin mulai timbul 15 menit setelah pemberian oral dan mencapai puncak dalam 2 jam. Efek analgetik timbul lebih cepat setelah pemberian subkutan atau IM yaitu dalam 10 menit, mencapai puncak dalam waktu 1 jam dan masa kerjanya 3-5 jam. ${ }^{6}$

Nyeri adalah suatu pengalaman sensorik dan emosional yang tidak menyenangkan yang berkaitan dengan kerusakan jaringan yang sudah atau berpotensi terjadi, atau dijelaskan berdasarkan kerusakan tersebut (Internasional Association for the Study of Pain [IASP] Task Force, 1994, p. 210211). Definisi ini menghindari pengkorelasian nyeri dengan suatu rangsangan (stimulus); definisi ini juga menekankan bahwa nyeri bersifat subyektif dan merupakan suatu sensasi sekaligus emosi. ${ }^{7}$

Rasa nyeri dapat dibagi menjadi dua jenis utama yaitu rasa nyeri cepat dan rasa nyeri lambat. Bila diberikan stimulus, rasa nyeri cepat timbul dalam waktu kira-kira 0,1 detik, sedangkan rasa nyeri lambat timbul setelah 1 detik atau lebih dan kemudian secara perlahan bertambah selama beberapa detik dan kadangkala bahkan beberapa menit. Rasa nyeri cepat juga digambarkan dengan banyak nama pengganti, seperti rasa nyeri tajam, rasa nyeri tertusuk, rasa nyeri akut, dan rasa nyeri tersetrum. Jenis rasa nyeri ini akan terasa bila sebuah jarum ditusukkan ke dalam kulit, bilskulit tersayat pisau, atau bila kulit terbakar secara akut. Rasa nyeri ini juga akan terasa bila subjek mendapat setrumen listrik. ${ }^{8}$

Rasa nyeri lambat juga mempunyai banyak nama seperti rasa nyeri terbakar lambat, nyeri pegal, nyeri nyeri berdenyutdenyut, nyeri mual, dan nyeri kronik. Jenis rasa nyeri ini biasanya dikaitkan dengan kerusakan jaringan. Rasa nyeri dapat berlangsung lama, menyakitkitkan dan dapat menjadi penderitaan yang tak tertahankan. Rasa nyeri ini dapat terasa dikulit dan hampir semua jaringan dalam atau organ. ${ }^{8}$

Banyak sruktur berperan dalam pemrosesan sensasi nyeri. Serat-serat nyeri aferen primer bersinaps dengan antarneuron ordo kedua spesifik di tanduk dorsal medula spinalis. Sebagai respons terhadap potensial aksi yang dipacu oleh rangsangan, serat-serat nyeri aferen mengeluarkan neurotransmiter yang mempengaruhi neuron-neuron berikutnya. Dua neurotransmiter yang paling banyak diketahui adalah substansi $\mathrm{P}$ dan glutamat. Substansi $\mathrm{P}$ mengaktifkan jalur-jalur asendens yang menyalurkan sinyal nosiseptif ke tingkat yang lebih tinggi. ${ }^{9}$ Semua informasi sensorik yang ditransmisikan ke sistem saraf pusat (SPP) dapat dimodulasi. ${ }^{10}$

\section{METODE PENELITIAN}

Desain penelitian ini yaitu analitik melalui pendekatan prospektif. Tempat penelitian ini dilakukan di bagian Anestesiologi dan Terapi Intensif di RSUP Prof. Dr. R. D. Kandou Manado pada bulan November 2014 sampai Desember 2014.. Sampel penelitian ini berjumlah 16 pasien seksio sesarea yang memenuhi kriteria inklusi dan eksklusi. Terdapat 10 pasien untuk kelompok ketorolak dan tramadol (kelompok I) dan 6 pasien untuk kelompok petidin (kelompok II) dipilih secara purposive sampling.

\section{HASIL PENELITIAN}

Penelitian ini dilakukan untuk 
membandingkan penggunaan ketorolak dan tramadol dengan petidin terhadap nilai nyeri pasien pasca operasi pada jam ke-0, jam ke-2, jam ke-4, dan jam ke-6. Tabel 1 menunjukkan bahwa terdapat 10 responden (62,5\%) yang dijadikan sampel penelitian dengan menggunakan analgesik ketorolak tramadol dan 6 responden (37,5\%) yang menggunakan analgesik petidin.

Tabel 1. Distribusi Berdasarkan Jenis Analgetik yang Diberikan

\begin{tabular}{ccc}
\hline Jenis Analgesik & $\mathrm{N}$ & $\%$ \\
\hline Ketorolak + tramadol & 10 & 62,5 \\
Petidin & 6 & 37,5 \\
Total & 16 & 100 \\
\hline
\end{tabular}

Pada Tabel 2 dapat dilihat kategori umur responden, dimana terdapat 4 kategori umur dengan frekuensi terbanyak yaitu umur 26, 30, 32 dan 40 tahun, masing-masing berjumlah 2 responden $(12,5 \%)$. Selebihnya terdiri atas masingmasing 1 responden (6,3\%).

Tabel 2. Distribusi Berdasarkan Umur Responden

\begin{tabular}{ccc}
\hline Umur & $\mathrm{N}$ & $\%$ \\
\hline 23 & 1 & 6,3 \\
24 & 1 & 6,3 \\
26 & 2 & 12,5 \\
28 & 1 & 6,3 \\
29 & 1 & 6,3 \\
30 & 2 & 12,5 \\
31 & 1 & 6,3 \\
32 & 2 & 12,5 \\
34 & 1 & 6,3 \\
40 & 2 & 12,5 \\
41 & 1 & 6,3 \\
43 & 1 & 6,3 \\
\hline Total & 16 & 100 \\
\hline
\end{tabular}

Data deskriptif statistik perbandingan tekanan darah, nadi, respirasi dan VAS dengan pemberian analgetik ketorolak + tramadol dan analgesik petidin jam ke-0, ke-2, ke-4, dan ke-6 dapat dilihat pada gambar-gambar berikut.

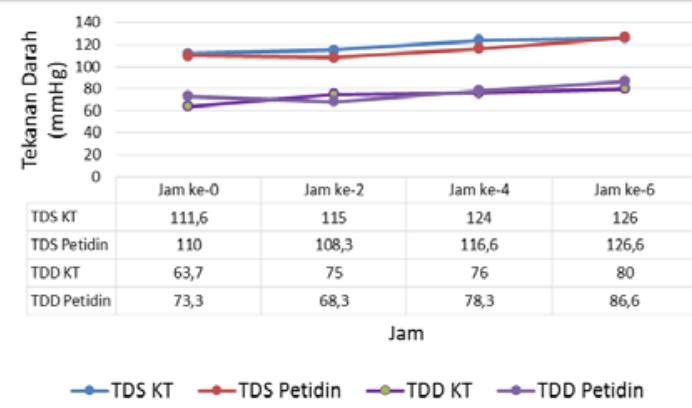

Gambar 1. Grafik Perbandingan Nilai Mean Tekanan Darah Berdasarkan Analgesik Ketorolak Tramadol dan Petidin Jam ke-0,ke-2, ke-4, ke-6

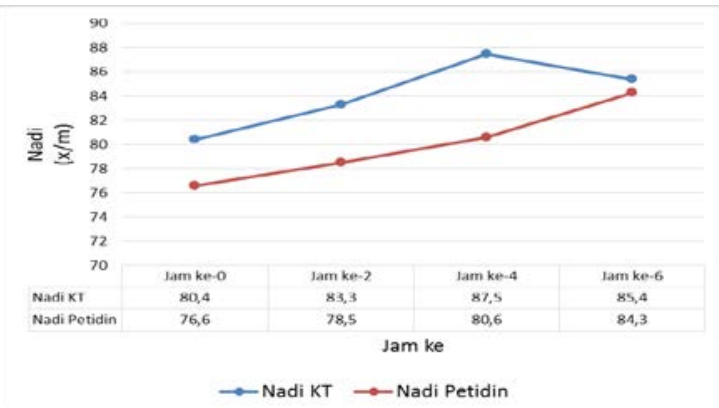

Gambar 2. Grafik perbandingan nilai Mean nadi berdasarkan analgesik ketorolak Tramadol dan Petidin Jam ke-0, ke-2, ke-4, ke-6

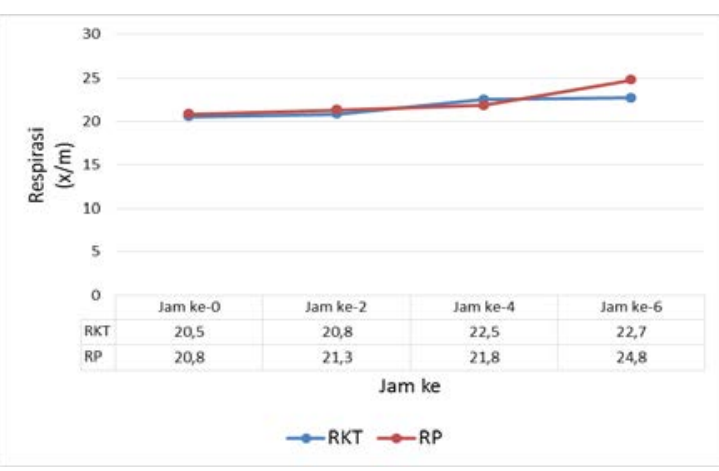

Gambar 3. Grafik perbandingan nilai Mean respirasi berdasarkan analgesik ketorolak tramadol dan petidin jam ke-0, ke-2, ke-4, ke-6

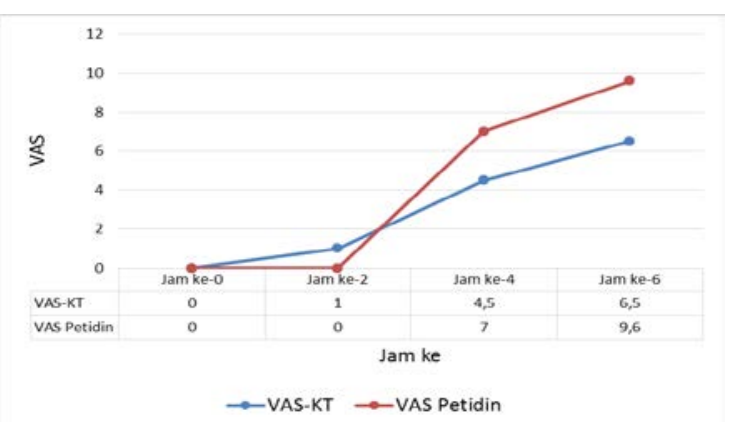

Gambar 4. Grafik perbandingan nilai Mean VAS berdasarkan analgesik ketorolak tramadol dan petidin jam ke-0, ke-2, ke-4, ke-6 
Perbandingan Nilai Minimum tekanan darah, nadi, respirasi dan VAS dengan pemberian analgetik ketorolak tramadol dan analgesik petidin jam ke-0, ke-2, ke-4, dan ke-6, dapat dilihat pada gambar-gambar berikut.

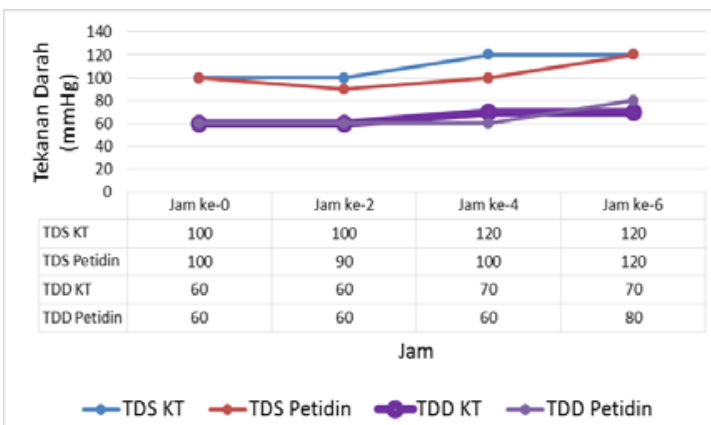

Gambar 5. Grafik Perbandingan Nilai Minimum Tekanan Darah Berdasarkan Analgesik Ketorolak Tramadol dan Petidin Jam ke-0, ke-2, ke-4, dan ke-6

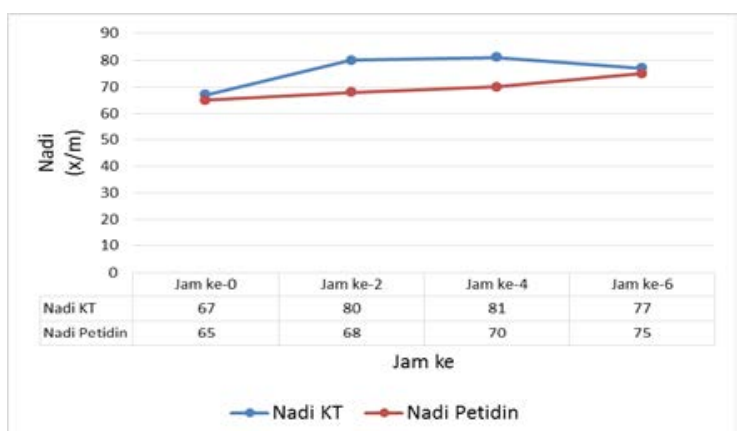

Gambar 6. Grafik Perbandingan Nilai Minimum Nadi Berdasarkan Analgesik Ketorolak Tramadol dan Petidin Jam ke-0, ke2, ke-4, ke-6

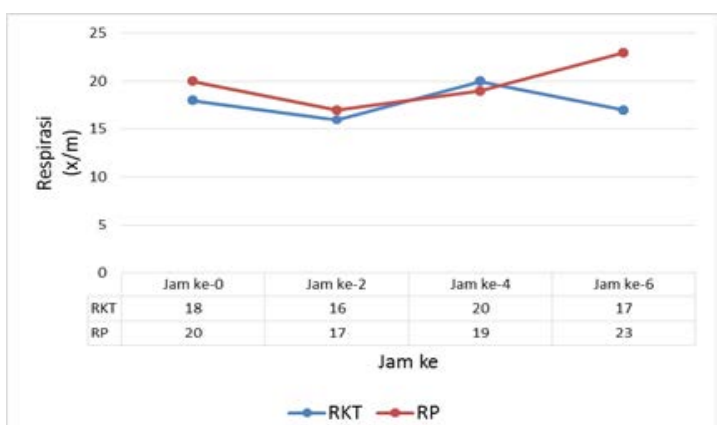

Gambar 7. Grafik Perbandingan Nilai Minimum Respirasi Berdasarkan Analgesik Ketorolak Tramadol dan Petidin Jam ke-0, ke2, ke-4, ke-6

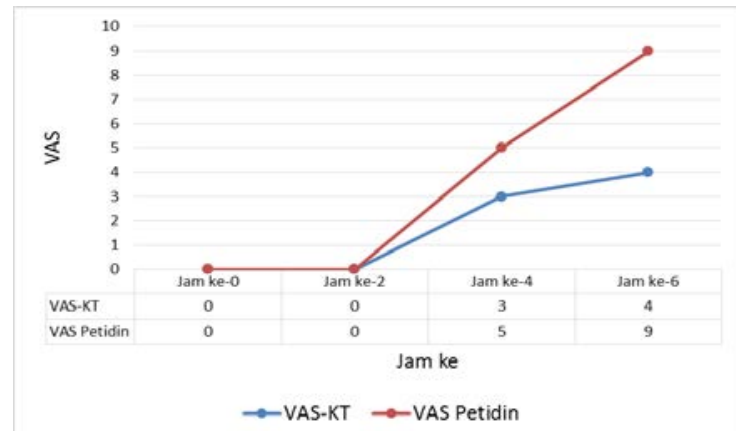

Gambar 8. Grafik Perbandingan Nilai Minimum VAS Berdasarkan Analgesik Ketorolak Tramadol dan Petidin Jam ke-0, ke2, ke-4, ke-6

Perbandingan Nilai Maksimum tekanan darah, nadi, respirasi dan VAS dengan pemberian analgetik ketorolak tramadol dan analgesik petidin jam ke- 0 , ke-2, ke-4, dan ke-6 dapat dilihat pada gambar-gambar berikut.

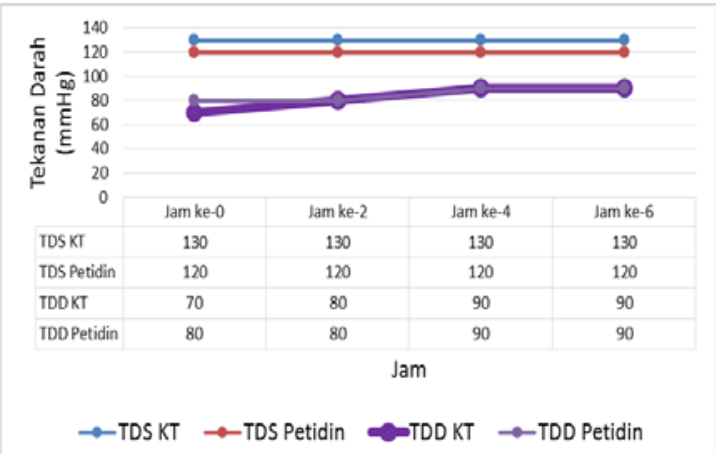

Gambar 9. Grafik Perbandingan Nilai Maksimum Tekanan Darah Berdasarkan Analgesik Ketorolak Tramadol dan Petidin Jam ke-0, ke-2, ke-4, ke-6

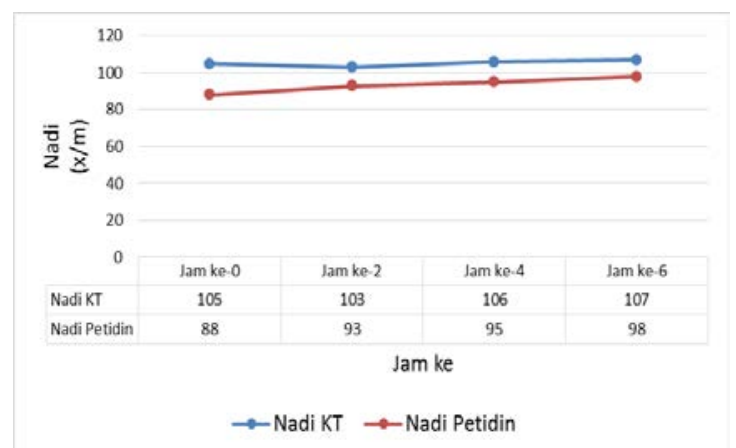

Gambar 10. Grafik Perbandingan Nilai Maximum Nadi Berdasarkan Analgesik Ketorolak Tramadol dan Petidin Jam ke-0, ke2, ke-4, ke-6 


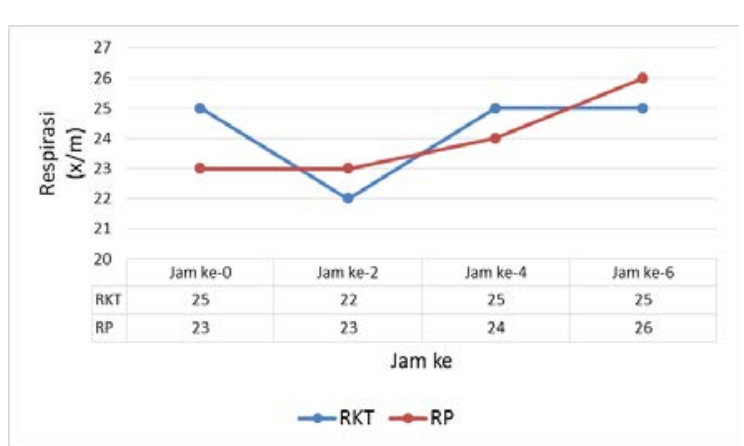

Gambar 11. Grafik Perbandingan Nilai Maximum Respirasi Berdasarkan Analgesik Ketorolak Tramadol dan Petidin Jam ke-0, ke2, ke-4, ke-6

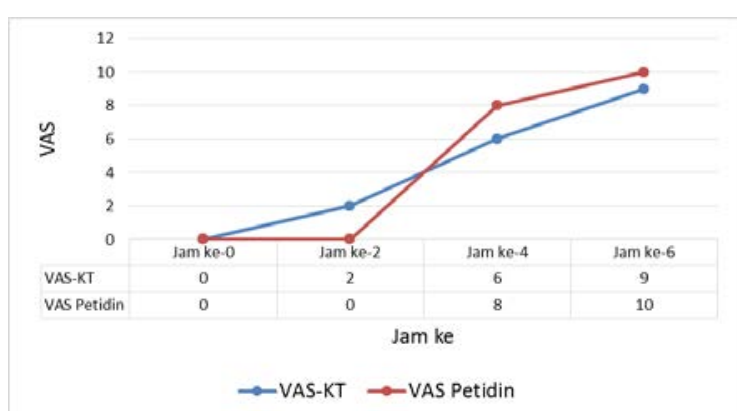

Gambar 12. Grafik Perbandingan Nilai Maximum VAS Berdasarkan Analgesik Ketorolak Tramadol dan Petidin Jam ke-0, ke2, ke-4, ke-6

Hasil analisis data menggunakan Mann-Whitney t-Test dapat dilihat pada Tabel 3 berikut.

Tabel 3. Analisis Perbandingan Ketorolak Tramadol dan PetidinMenggunakan MannWhitney t-Test

\begin{tabular}{ccc}
\hline Item & z-value & Sig. \\
\hline TDS Jam ke-0 & 0,114 & 0,909 \\
TDD Jam ke-0 & 2,309 & 0,021 \\
TDS Jam ke-2 & 1,296 & 0,195 \\
TDD Jam ke-2 & 1,696 & 0,090 \\
TDS Jam ke-4 & 2,000 & 0,046 \\
TDD Jam ke-4 & 0,804 & 0,421 \\
TDS Jam ke-6 & 0,258 & 0,796 \\
TDD Jam ke-6 & 1,912 & 0,056 \\
Nadi Jam ke-0 & 0,110 & 0,912 \\
Nadi Jam ke-2 & 1,179 & 0,238 \\
Nadi Jam ke-4 & 1,659 & 0,097 \\
Nadi Jam ke-6 & 0,170 & 0,865 \\
Respirasi Jam ke-0 & 0,775 & 0,450 \\
Respirasi Jam ke-2 & 1,047 & 0,295 \\
Respirasi Jam ke-6 & 1,678 & 0,093 \\
VAS Jam ke-0 & 0,000 & 1,000 \\
VAS Jam ke-2 & 2,023 & 0,043 \\
\hline
\end{tabular}

Berdasarkan tabel 3 terlihat bahwa tidak terdapat perbedaan tekanan darah sistolik pada jam ke-0 baik pada kelompok analgesik ketorolak tramadol maupun kelompok analgesik petidin $(\mathrm{p}=0,909)$. Terdapat perbedaan tekanan darah diastolik jam ke-0 pada kelompok analgesik ketorolak tramadol maupun kelompok analgesik petidin $(\mathrm{p}=0,021)$. Tidak terdapat perbedaan tekanan darah sistolik jam ke-2 pada kelompok analgesik ketorolak tramadol maupun kelompok analgesik petidin $\quad(p=0,195)$ Tidak terdapat perbedaan tekanan darah diastolik jam ke-2 pada kelompok analgesik ketorolak tramadol maupun kelompok analgesik petidin $(\mathrm{p}=0,090)$. Terdapat perbedaan tekanan darah sistolik jam ke-4 pada kelompok analgesik ketorolak tramadol maupun kelompok analgesik petidin $(\mathrm{p}=$ 0,046). Tidak terdapat perbedaan tekanan darah diastolik jam ke-4 pada kelompok analgesik ketorolak tramadol maupun kelompok analgesik petidin $(\mathrm{p}=0,421)$. Tidak terdapat perbedaan tekanan darah sistolik jam ke-6 pada kelompok analgesik ketorolak tramadol maupun kelompok analgesik petidin $(\mathrm{p}=0,796)$. Tidak terdapat perbedaan tekanan darah diastolik jam ke-6 pada kelompok analgesik ketorolak tramadol maupun kelompok analgesik petidin $(\mathrm{p}=0,056)$. Tidak terdapat perbedaan nadi jam ke-0 pada kelompok analgesik ketorolak tramadol maupun kelompok analgesik petidin $(\mathrm{p}=0,912)$. Tidak terdapat perbedaan nadi jam ke-2 pada kelompok analgesik ketorolak tramadol maupun kelompok analgesik petidin $(\mathrm{p}=0,238)$. Tidak terdapat perbedaan nadi jam ke-4 pada kelompok analgesik ketorolak tramadol maupun kelompok analgesik petidin $\quad(p=0,097)$ Tidak terdapat perbedaan nadi jam ke-6 pada kelompok analgesik ketorolak tramadol maupun kelompok analgesik petidin $(\mathrm{p}=0,865)$. Tidak terdapat perbedaan respirasi jam ke-0 pada kelompok analgesik ketorolak tramadol maupun kelompok analgesik petidin $\quad(p=0,450)$ Tidak terdapat perbedaan respirasi jam ke-2 pada kelompok analgesik ketorolak tramadol 
maupun kelompok analgesik petidin $(\mathrm{p}=$ 0,295 ). Tidak terdapat perbedaan respirasi jam ke-6 pada kelompok analgesik ketorolak tramadol maupun kelompok analgesik petidin $(\mathrm{p}=0,093)$. Tidak terdapat perbedaan skor VAS jam ke-0 pada kelompok analgesik ketorolak tramadol maupun kelompok analgesik petidin ( $\mathrm{p}=$ 1,000) dan terdapat perbedaan skor VAS jam ke-2 pada kelompok analgesik ketorolak tramadol maupun kelompok analgesik petidin $(\mathrm{p}=0,043)$.

\section{BAHASAN}

Terdapat 16 responden penelitian, yang dibagi dalam dua kelompok. Kelompok yang satu ialah kelompok yang mendapatkan analgesik ketorolak tramadol yang berjumlah 10 responden (62,5\%) dan kelompok yang lain mendapatkan analgesik petidin yang berjumlah 6 responden (37,5\%). Variasi umur responden berada pada rentang usia 23 tahun sampai 43 tahun.

Hasil analisis statistik deskriptif tekanan darah menunjukkan bahwa pada responden kelompok ketorolak tramadol, tekanan darah sistolik diastolik terlihat mengalami peningkatan nilai rata-rata dari jam ke-2 sampai jam ke-6, sedangkan pada kelompok petidin, terjadi penurunan nilai dari jam ke-0 ke jam ke-2, dan meningkat setelah jam ke-4 dan jam ke-6. Hasil uji statistik dengan menggunakan MannWhitney $U$ Test menunjukkan tidak terdapat perbedaan tekanan darah sistolik pada jam ke-0 pada kelompok ketorolak tramadol dan kelompok petidin $(\mathrm{p}=0,090)$. Terdapat perbedaan tekanan darah diastolik pada jam ke-0 pada kelompok ketorolak tramadol dan kelompok petidin $(p=0,021)$. Tidak terdapat perbedaan tekanan darah sistolik dan diastolik pada jam ke-2 pada kelompok ketorolak tramadol dan kelompok petidin $(\mathrm{p}=0,090 ; \mathrm{p}=0,090)$. Terdapat perbedaan tekanan darah sistolik pada jam ke-4 pada kelompok ketorolak tramadol dan kelompok petidin $(\mathrm{p}=0,046)$. Tidak terdapat perbedaan tekanan darah diastoik pada jam ke-4 pada kelompok ketorolak tramadol dan kelompok petidin $(\mathrm{p}=0,421)$. Tidak terdapat perbedaan tekanan darah sistolik pada jam ke-6 pada kelompok ketorolak tramadol dan kelompok petidin $(\mathrm{p}=0,796)$. Tidak terdapat perbedaan tekanan darah diastolik pada jam ke-6 pada kelompok ketorolak tramadol dan kelompok petidin $(p=0,056)$. Secara keseluruhan, perbandingan tekanan darah baik pada kelompok ketorolak tramadol dan petidin tidak menunjukkan perbedaan yang signifikan.

Hasil analisis statistik deskriptif nadi menunjukkan bahwa baik pada responden kelompok analgesik ketorolak tramadol dan analgesik petidin, nadi terlihat mengalami peningkatan nilai rata-rata dari jam ke-0 sampai jam ke-6. Hasil uji statistik menggunakan Mann-Whitney $U$ Test menunjukkan bahwa tidak terdapat perbedaan nadi pada kelompok ketorolak tramadol dan petidin pada jam ke-0, ke-2, ke-4, dan ke-6 ( $>>0,05)$. Hasil analisis statistik deskriptif nadi menunjukkan bahwa baik pada responden kelompok analgesik ketorolak tramadol dan analgesik petidin, respirasi terlihat mengalami peningkatan nilai rata-rata dari jam ke-0 sampai jam ke-6. Hasil uji statistik menggunakan Mann-Whitney $U$ Test menunjukkan bahwa tidak terdapat perbedaan respirasi pada kelompok ketorolak tramadol dan petidin pada jam ke-0, ke-2, ke-4, dan ke-6 ( $\mathrm{p}>0,05)$.

Hasil analisis statistik deskriptif VAS menunjukkan bahwa baik pada responden kelompok analgesik ketorolak tramadol dan analgesik petidin, skor VAS terlihat mengalami peningkatan nilai rata-rata dari jam ke-0 sampai jam ke-6. Pada kelompok petidin, jam ke-0 sampai jam ke-2, tidak ada perubahan skor VAS, tetapi meningkat pada jam ke-4 dan jam ke-6 pasca pembedahan. Pada kedua jenis analgesik ini, skor VAS meningkat secara drastis pada jam ke-4 dan jam ke-6. Hasil uji statistik menggunakan $t$-Test menunjukkan bahwa terdapat perbedaan skor VAS pada kelompok ketorolak tramadol dan petidin pada jam ke-4 dan jam ke-6 ( $\mathrm{p}=0,001 ; \mathrm{p}=$ 0,000).

Penggunaan berbagai analgesik 
menjadi tren dalam kegiatan pembedahan. melakukan penelitian efektifitas ketamin dan tramadol terhadap nyeri penyuntikan pada induksi anastesi. Hasilnya efek analgesia pada pemakaian ketamin lebih efektif secara bermakna dibandingkan dengan kelompok tramadol dalam mengurangi nyeri saat induksi propofol. Penelitian Sulystiowati (2009) tentang perbedaan pengaruh pemberian ketorolak dan deksketoprofen sebagai analgesia pasca bedah terhadap agregasi trombosit menunjukkan bahwa ketorolak dapat mengurangi persentase skala nyeri pasca bedah terhadap agregasi trombosit. Setyono (2009) menyatakan pada kasus lain efek ketorolak dan deksketoprofen yang merupakan golongan obat antiinflamasi nonsteroid (OAINS). Kemampuan OAINS untuk mengatasi nyeri dapat digunakan untuk pengelolaan nyeri pascabedah. Secara umum OAINS menghambat aktivitas enzim siklooksigenase (COX) sehingga sintesis prostaglandin terhambat. Hambatan pada enzim COX-1 akan menghambat sintesis tromboksan A2 sehingga akan mempengaruhi waktu perdarahan. Hasil penelitiannya menunjukkan ketorolak intravena menyebabkan waktu perdarahan lebih panjang dibandingkan deksketoprofen intravena.

\section{SIMPULAN}

1. Terdapat perbedaan rasa nyeri yang sangat bermakna pada jam ke-4 dan jam ke-6 antara pemberian ketorolak + tramadol dan pemberian petidin

2. Nilai rerata VAS pada pemberian ketorolak dan tramadol lebih rendah dibandingkan dengan nilai rerata VAS patda pemberian petidin

\section{SARAN}

Pada penderita seksio sesarea dengan menggunakan anestesi spinal dapat dianjurkan pemakaian analgetik ketorolak + tramadol.

\section{UCAPAN TERIMA KASIH}

Ucapan terima kasih disampaikan kepada Dr. dr. Hermanus. J. Lalenoh, SpAn, KAO, KMN dan dr. Deiby D. Wuisan, SpAn serta semua pihak, baik secara langsung maupun tidak langsung, yang telah memberikan ide dan gagasan kepada penulis dalam menyelesaikan artikel ini.

\section{DAFTAR PUSTAKA}

1. Ratna SF, Susilo C. Buku Ajar Anestesiologi dan Intensive Care. Jakarta: Fakultas Kedokteran Universitas Indonesia/RS Cipto Mangunkusumo, 2012.

2. Wiknjosastro H, Saifuddin AB, Rachimhadhi T. Ilmu bedah kebidanan (1st ed). Jakarta: PT Bina Pustaka Sarwono Prawirohardjo, 2010.

3. Latief S, Suryadi K, Dachlan M. Petunjuk praktis anestesiologi (2nd ed). Jakarta: Bagian anestesiologi dan terapi intensif Fakultas Kedokteran Universitas Indonesia, 2001.

4. Hurley RW, Wu LC. Acute postoperative pain. In: Miller RD, Eriksson LI, Fleisher LA, Wiener-Kronish JP, Young WL, editors. Miller's Anesthesia (7th ed). Philadelphia: Elsevier, 2010.

5. Gunawan SG, Setiabudy R, Nafrialdi, Elysabeth. Farmakologi dan terapi (5th ed). Cetak Ulang dengan tambahan. Jakarta: Badan Penerbit FKUI, 2007.

6. Farmasiku.com/index. Ph pitarge $=$ categories dan category_id=Page=10 (cited 2014 Oct 11).

7. Sylvia PA, Lorraine WM. Patofisiologi Konsep Klinis Proses - Proses Penyakit (6th ed). Jakarta: EGC, 2012; p. 10635.

8. Guyton A, Hall JE. Fisiologi Kedokteran (11th ed). Jakarta: EGC, 2008.

9. Keat S, Bate S T. Anaesthesia on the move. Mackinnon R, Keat S, Locke T, Walker A, editors. Jakarta: PT Indeks Permata, 2013.

10. AGS Panel on Persistent Pain in Older Person. The managemant of persistent pain in older persons. J Am Geriart Soc. 2002;50(S6):205-24. 